\title{
Geospatial Modeling to Assess The Land Suitability of Mangrove Restoration at Bantul Regency, Yogyakarta, Indonesia
}

\author{
Kanti Suraningsih ${ }^{1 *}$, Hartuti Purnaweni ${ }^{1,2}$, and Muhammad Helmi ${ }^{1,3,4}$ \\ ${ }^{1}$ Master Program of Environmental Sciences, School of Postgraduate, Diponegoro University, \\ Semarang-Indonesia \\ ${ }^{2}$ Doctoral Program of Environmental Sciences, School of Post-Graduation, Diponegoro University, \\ Semarang-Indonesia \\ ${ }^{3}$ Department of Oceanography, Faculty of Fisheries and Marine Sciences, Diponegoro University, \\ Semarang-Indonesia \\ ${ }^{4}$ Center of Coastal Rehabilitation and Disaster Mitigation Studies (CoREM), Diponegoro University, \\ Semarang-Indonesia
}

\begin{abstract}
The geo-position of Bantul Regency, which has open seas directly facing the Indian Ocean, is very vulnerable to tsunami and abrasion hazards, therefore disaster mitigation is needed in the form of restoring mangrove forest ecosystems. The purpose of this study was to assess the land suitability of mangrove restoration. The method used in this research is geospatial modelling that utilizes field surveys and interviews. The parameters tested consisted of maximum inundation, inundation frequency and land use. The results showed the potential for mangrove restoration as disaster mitigation at the Opak river estuary in Tirtohargo Village Kretek District and Rejosari Village in Sanden District. The Progo River estuary is also a mangrove restoration area in Poncosari Village, Srandakan District. After doing the geospatial analysis, it was found that the potential for mangrove forest restoration with a very suitable class was 168 ha and a suitable class was 181 ha. This mangrove forest is highly recommended because it physically has a coastal defence, protecting beaches and river banks, and prevents seawater abrasion.
\end{abstract}

\section{Introduction}

The total area of mangroves in 2000 was $137,760 \mathrm{~km}^{2}$; it was located in 118 countries and regions in tropical and subtropical regions of the world. Almost $75 \%$ of the world's mangroves are found only in 15 countries, and only $6.9 \%$ are protected under the existing network of protected areas (IUCN I -IV) [1]. At the same time, mangrove forests have great potential in supporting the development of SDGs (Sustainable Development Goals). SDGs is a global and national commitment to improve the welfare of society. 1 of 17 SDGs contributed by mangrove forests is Addressing Climate Change [2]. The restoration of mangroves in the Indonesian archipelago with carbon-rich should be a component of a high

* Corresponding author: kantisuraningsih@students.undip.ac.id 
priority strategy for climate change mitigation [3]. Mangroves can deal with climate change because mangroves can store higher carbon than tropical forests. Mangrove forests typically contain $1,023 \mathrm{Mg}$ of carbon per hectare. The organic-rich soil ranges from $0.5 \mathrm{~m}$ to more than $3 \mathrm{~m}$ deep and accounts for $49-98 \%$ of carbon storage in the system [4].

Indonesia has the largest mangrove forest in the world. The area is about 3.2 million ha which is $22.6 \%$ of the world's total mangrove [5]. However, in the last two to three decades, almost $50 \%$ of the total mangroves in Indonesia have been lost, from around 6.7 million ha to about 3.2 million ha [6]. The islands of Java and Bali were the islands with the most significant damage, around $88 \%$. Previously, these two islands had about 171,500 ha, but currently, there is only 19,577 ha [7]. It is regrettable if the mangroves area was converted into commercial areas such as settlements, aquaculture, rice fields, etc. When mangroves area is lost, it will cause the threat of erosion, abrasion, tsunami, land subsidence, etc.

The mangrove forest in Bantul Regency is located at Baros Hamlet, Tirtohargo Village, Kretek District, with about 4 ha [8]. The suitability of mangrove land in Bantul has been studied, but only limited to Baros hamlet [9]. Meanwhile, the Bantul coast is an open sea area that directly faces the Indian Ocean. The Bantul coast, precisely in the estuary waters of the Opak River and the Progo River, has a significant impact in the event of a tsunami [10, 11]. Therefore, mitigation efforts are needed to prevent this condition. Mangrove forests are an effort that can be made to reduce the impact of disasters. Therefore, this study aims to analyze the suitability of mangrove restoration land in the Bantul Regency.

\section{Materials and methods}

\subsection{Study dan Sampling Area}

The soil sampling and observations were taken from April to May 2021. The determination of the sampling point was carried out with the help of the Ach GIS 10.6.1 software. There were 39 sample points from the mouth of the Opak River in Tirtohargo village, Kretek district and Rejosari village at Sanden district, also the estuary area on the Progo River in Poncosari village, Srandakan district. The research sites can be seen in figure 1 . The measurements of the study were made by direct observation in the field.

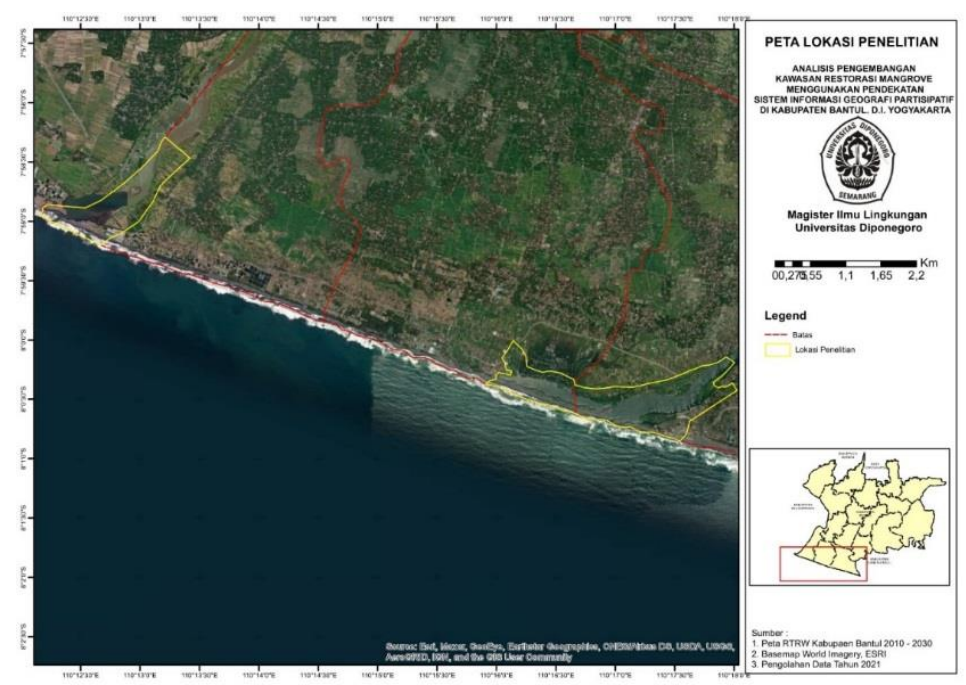

Fig. 1. Research sites. 


\subsection{Analysis of Mangrove Land Suitability}

The obtained data were then analyzed using the scoring method on physical parameters. Therefore it could evaluate the mangrove land. Land suitability classification is carried out by compiling a suitability matrix to assess the feasibility based on scoring on the mangrove boundary parameters (Table 1). Each parameter was divided into three classes in this study, namely very suitable, suitable, and conditionally suitable. The very suitable class is given a value of 3 , the suitable class is given a value of 2 , and the conditionally suitable class is given a value of 1 . Furthermore, every single parameter in this study is weighted based on a literature study to assess or determine the level of land suitability. Parameters that have a more substantial effect are given a higher weight than those with a weaker effect. The total score from the multiplication of the parameter values and their weights is then used as a formula to determine the suitability class for mangrove land [12].

$$
Y=\sum \text { ai.Xn }
$$

Information :

$\mathrm{Y}=$ Total land suitability value

ai $=$ weighting factor

$\mathrm{Xn}=$ Value of land suitability

The land suitability class interval is obtained based on the Equal Interval method [12]

$$
I=\frac{\left(\sum a i . X n\right)-\left(\sum a i . X n\right) \min }{k}
$$

Information :

$\mathrm{i}=$ Land suitability class interval

$\mathrm{k}=$ Number of land suitability classes desired

Based on the formula and calculations above, the class interval and value (score) of land suitability are obtained as follows:

$\mathrm{S} 1=$ very suitable, with a value of $11-15$

$\mathrm{S} 2=$ suitable, with a value of $6-10$

S3 = conditionally suitable, with a value of 1 - 5

\begin{tabular}{|c|c|c|c|c|}
\hline NO & PARAMETER & CLASS & VALUE & WEIGHT \\
\hline \multirow{3}{*}{1} & \multirow{3}{*}{$\begin{array}{l}\text { maximum inundation height } \\
(\mathrm{m})\end{array}$} & $<0,5$ & 3 & \multirow{3}{*}{2} \\
\hline & & $0,5-1$ & 2 & \\
\hline & & $>1$ & 1 & \\
\hline \multirow{3}{*}{2} & \multirow{3}{*}{$\begin{array}{l}\text { Inundation frequency } \\
\text { (Day / month) }\end{array}$} & 20 & 3 & \multirow{3}{*}{2} \\
\hline & & $10-19$ & 2 & \\
\hline & & $<10$ atau $>20$ & 1 & \\
\hline
\end{tabular}

Table 1. Matrix of Criteria Mangrove Land Suitability. 


\begin{tabular}{|l|l|c|c|c|}
\hline \multirow{3}{*}{3} & \multirow{3}{*}{3} & $\begin{array}{c}\text { Mangrove, forest, open } \\
\text { land }\end{array}$ & \multirow{2}{*}{3} \\
\cline { 3 - 4 } & Land use & Mining, aquaculture & 2 & \multirow{2}{*}{1} \\
\cline { 3 - 4 } & & Residential, industrial & 1 & \\
\hline
\end{tabular}

\subsection{Geospatial Modelling}

The progress of geospatial analysis is currently very fantastic; world researchers in various fields use it. In the agriculture sector, it is used to determine the distribution of insecticide residues $[13,14]$. For example, in the marine sector, it is used by marine experts at marine biodiversity conservation and coastal blue carbon ecosystems [15-17]. In the environment and anti-disaster management, it is applied to earthquake intensity assessment and making tsunami vulnerability index maps [18]. The spatial analysis method can be combined with other analysis methods such as Hierarchy Component Analysis (HCA) and Principal Component Analysis (PCA), which is then called multivariate statistical analysis [19] because the technique is proven to be flexible and practical in many ways. Geospatial modelling in this research is used to determine a suitable area for mangroves. The main thing in the modelling geospatial mapping process, it can also be done using remote sensing from a satellite platform [20].

The research of the suitability of mangrove land was taken from coordinate points that previously used Microsoft Excel. It was converted into a mapping system using ArcGIS 16.1. ArcGIS software was essential in determining geographic information both inland and water, such as length of the coast, level of abrasion and changes in shoreline [21]. GIS technology integrates a joint database operation, such as querying and statistical analysis, with mapping a unique visualization and analyzing capabilities. This ability is what distinguishes Geospatial Information Systems from other Information Systems [22]. This mangrove land suitability modelling also uses the Bantul Regency Spatial Plan and ESRI's Basemap World Imagery.

\section{Results and discussions}

The maximum inundation height $(\mathrm{MIH})$ yields the highest yield in the Srandakan district, namely $155 \mathrm{~cm}$ (Table 2) (Fig. 3). Meanwhile, the lowest maximum inundation height was at stations $\mathrm{Sa} 6, \mathrm{Sa}$, and $\mathrm{Sa} 9$ in Sanden District (Fig. 2). The tides influence inundation height in the region. The tides in the Bantul regency are at a high level of vulnerability. The tidal value of the Bantul coast has an average of $1.3 \mathrm{~m}$ [23]. The tides in the sea significantly affect the inundation height in estuary waters.

Meanwhile, the tides in the Bantul regency have caused erosion. This is because the movement of geomorphological power from west to east occurs due to the strengthening of the coast in the Kulonprogo Regency concerning YIA (Yogyakarta International Airport) [24]. It is also coupled with an angle between the direction of the waves and the coastline, which is reflected by littoral drift.

Table 2. The average value of maximum inundation height and inundation frequency at each location point. 


\begin{tabular}{|c|c|c|c|c|c|c|c|c|}
\hline $\begin{array}{l}\text { Station } \\
\text { Kretek }\end{array}$ & $\begin{array}{l}\text { MIH } \\
\text { (cm) }\end{array}$ & $\begin{array}{c}\text { FI } \\
\text { (day/ } \\
\text { month) }\end{array}$ & $\begin{array}{l}\text { Station } \\
\text { Sanden }\end{array}$ & $\begin{array}{l}\text { MIH } \\
(\mathrm{cm})\end{array}$ & $\begin{array}{c}\text { FI } \\
\text { (day/ } \\
\text { month) }\end{array}$ & $\begin{array}{c}\text { Station } \\
\text { Srandaka } \\
\mathbf{n}\end{array}$ & $\begin{array}{l}\text { MIH } \\
\text { (cm) }\end{array}$ & $\begin{array}{l}\text { FI (day/ } \\
\text { month) }\end{array}$ \\
\hline $\mathrm{Kr} 1$ & 110 & 20 & Sal & 70 & 15 & Sr1 & 150 & 26 \\
\hline $\mathrm{Kr} 2$ & 100 & 20 & $\mathrm{Sa} 2$ & 80 & 20 & $\mathrm{Sr} 2$ & 145 & 26 \\
\hline $\mathrm{Kr} 3$ & 90 & 20 & $\mathrm{Sa} 3$ & 90 & 18 & Sr3 & 155 & 26 \\
\hline $\mathrm{Kr} 4$ & 80 & 18 & $\mathrm{Sa} 4$ & 100 & 16 & $\mathrm{Sr} 4$ & 70 & 20 \\
\hline $\mathrm{Kr} 5$ & 70 & 20 & $\mathrm{Sa} 5$ & 60 & 15 & $\mathrm{Sr} 5$ & 80 & 22 \\
\hline Kr6 & 70 & 20 & $\mathrm{Sa} 6$ & 50 & 16 & Sr6 & 85 & 22 \\
\hline $\mathrm{Kr} 7$ & 80 & 18 & $\mathrm{Sa} 7$ & 60 & 18 & $\mathrm{Sr} 7$ & 90 & 20 \\
\hline $\mathrm{Kr} 8$ & 100 & 17 & $\mathrm{Sa} 8$ & 50 & 22 & Sr8 & 75 & 20 \\
\hline $\mathrm{Kr} 9$ & 120 & 20 & $\mathrm{Sa} 9$ & 50 & 20 & $\mathrm{Sr} 9$ & 125 & 23 \\
\hline $\mathrm{Kr} 10$ & 100 & 21 & Sa10 & 70 & 23 & Sr10 & 80 & 20 \\
\hline Kr11 & 110 & 24 & Sa11 & 70 & 24 & & & \\
\hline $\mathrm{Kr} 12$ & 120 & 25 & Sa12 & 120 & 21 & & & \\
\hline $\mathrm{Kr} 13$ & 70 & 21 & & & & & & \\
\hline Kr14 & 80 & 22 & & & & & & \\
\hline Kr15 & 60 & 23 & & & & & & \\
\hline Kr16 & 60 & 20 & & & & & & \\
\hline Kr17 & 70 & 21 & & & & & & \\
\hline
\end{tabular}

This is different when compared to research that was conducted on the north coast of Java. Because many factors influence inundation include sea-level rise and land subsidence. The relatively high sea-level rise and land subsidence can result in tides, obviously where the sea level reaches a height that exceeds normal conditions [25]. Whereas in mangrove planting, the best maximum inundation height is below $0.5 \mathrm{~m}$. 

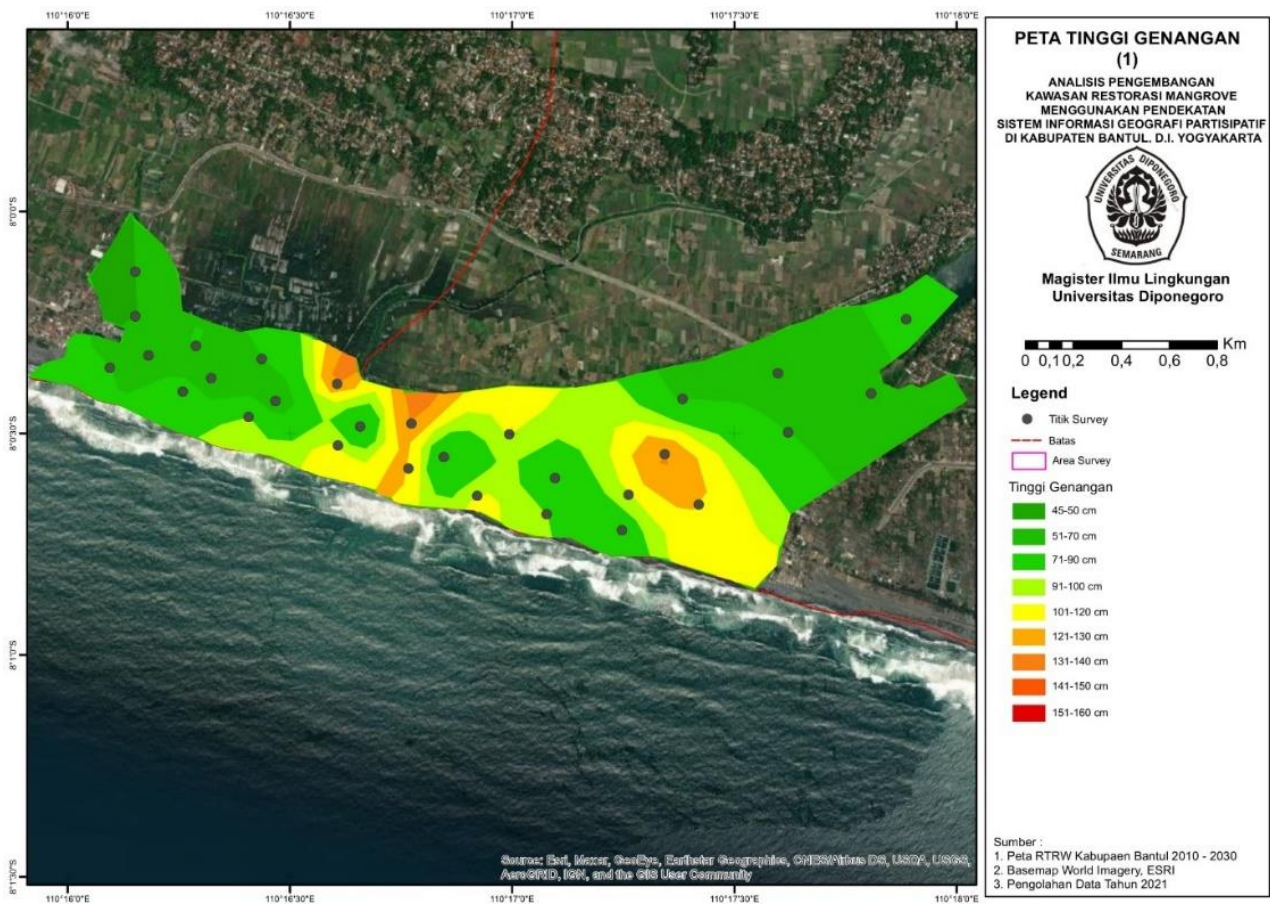

Fig. 2. Map of maximum inundation height in Kretek and Sanden Districts, Bantul Regency, Indonesia.
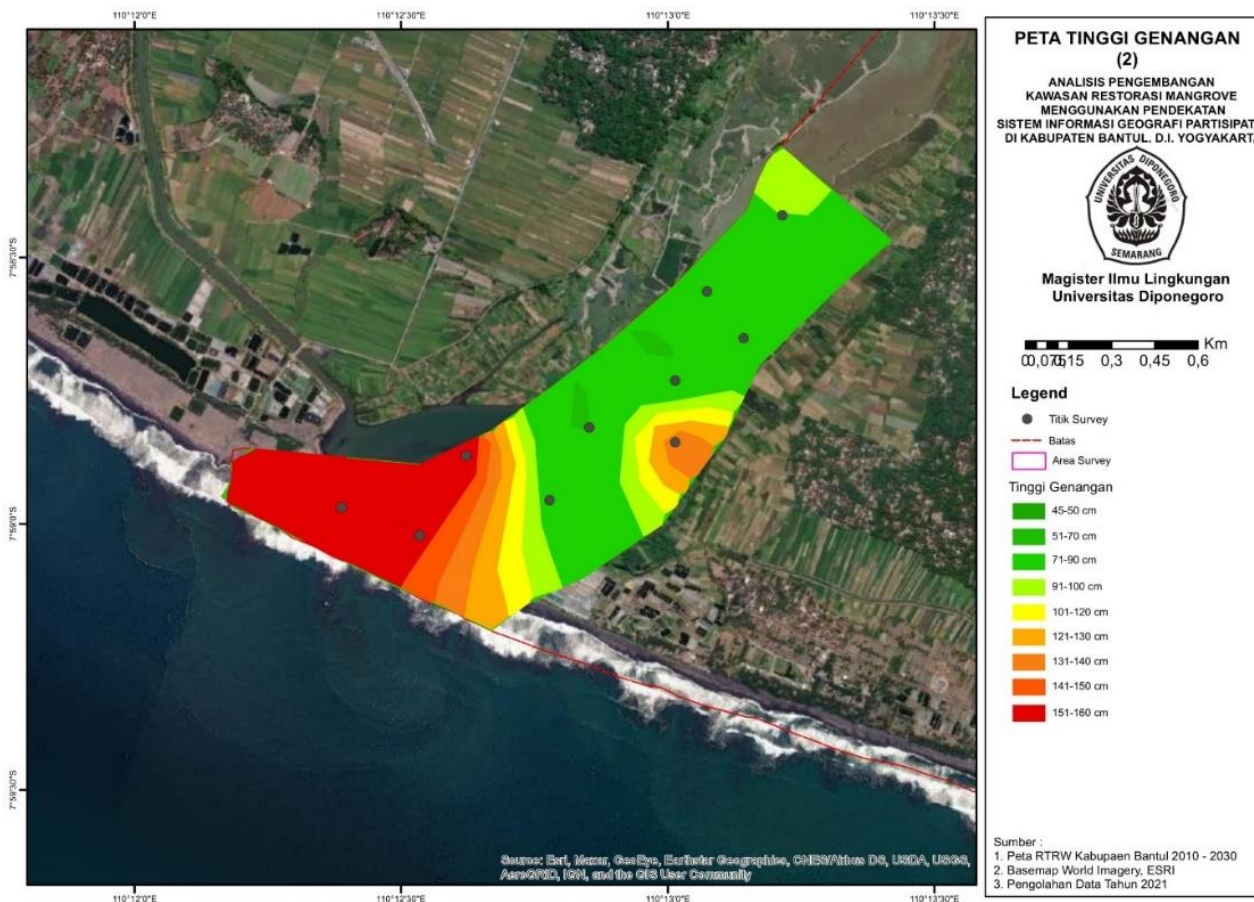

Magister Ilmu Lingkungan Universitas Diponegoro

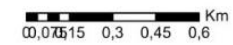

\section{Legend}

- Trik Survey

- Batas

$\square$ Area Survey
Tinggi Genangan

Tinggi Genangan

$51-70 \mathrm{~cm}$
$71-90 \mathrm{~cm}$

D1-90 cm

91-100 cm
$101-120 \mathrm{~cm}$

121-130 om

$131-140 \mathrm{~cm}$

141-150 cm

$151.160 \mathrm{~cm}$

Sumber:

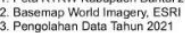

Fig. 3. Map of maximum inundation height in Srandakan Districts, Bantul Regency, Indonesia. 
Results the highest frequency inundation (FI) occurred at stations $\mathrm{Sr} 1, \mathrm{Sr} 2$, and $\mathrm{Sr} 3$ in the district of Srandakan at 30 days/month. Meanwhile, the lowest inundation frequency was found at the Sa1 and Sa5 stations in the Sanden district (15 days/month). This is different from research in Tugu district, Semarang City; the research obtained inundation frequency results of 30-31 days per month [12]. This is due to the selection of Semarang mangrove land on the north coast so that it has a high frequency of inundation. It is also supported because the north coast is not directly facing the ocean.

Meanwhile, the selection of mangrove land on the south coast is more optimal in the estuary area. The statement confirms that mangrove ecosystems will live optimally in areas protected from large currents and waves, such as coastal areas with large river estuaries and deltas, where water flow contains much mud. Mangroves are challenging to grow in coastal areas that are steep and wavy with strong tidal currents. These conditions do not allow for siltation to occur as a substrate for growth [26]. The inundation frequency parameter was also strengthened by research that almost all of the coasts in Bantul Regency, including sandy beaches [27]. It also causes shoreline changes, coastal erosion and sedimentation, and frequent changes in the inundation frequency in the estuary.

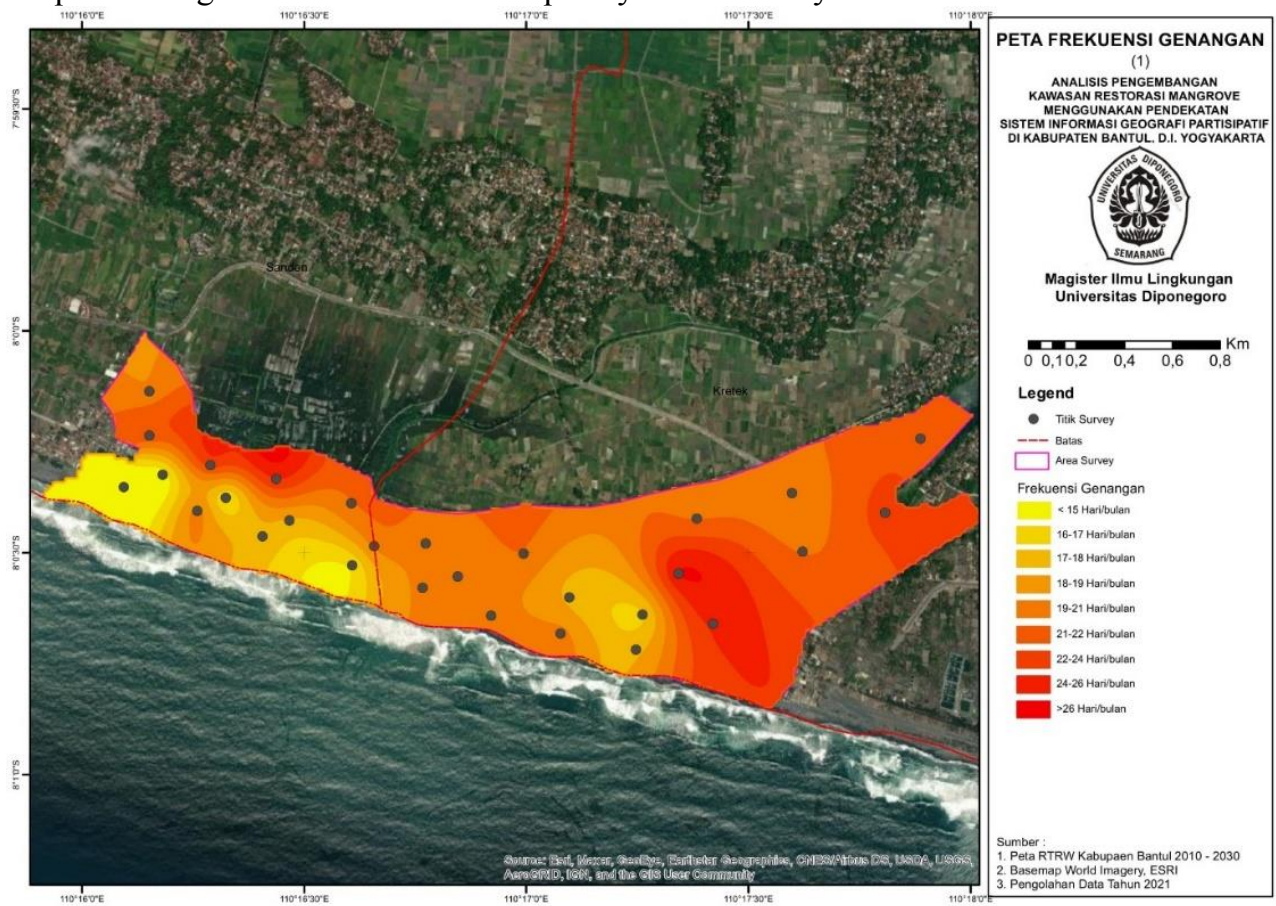

Fig. 4. Map of frequency inundation at Kretek and Sanden Districts, Bantul Regency, Indonesia 


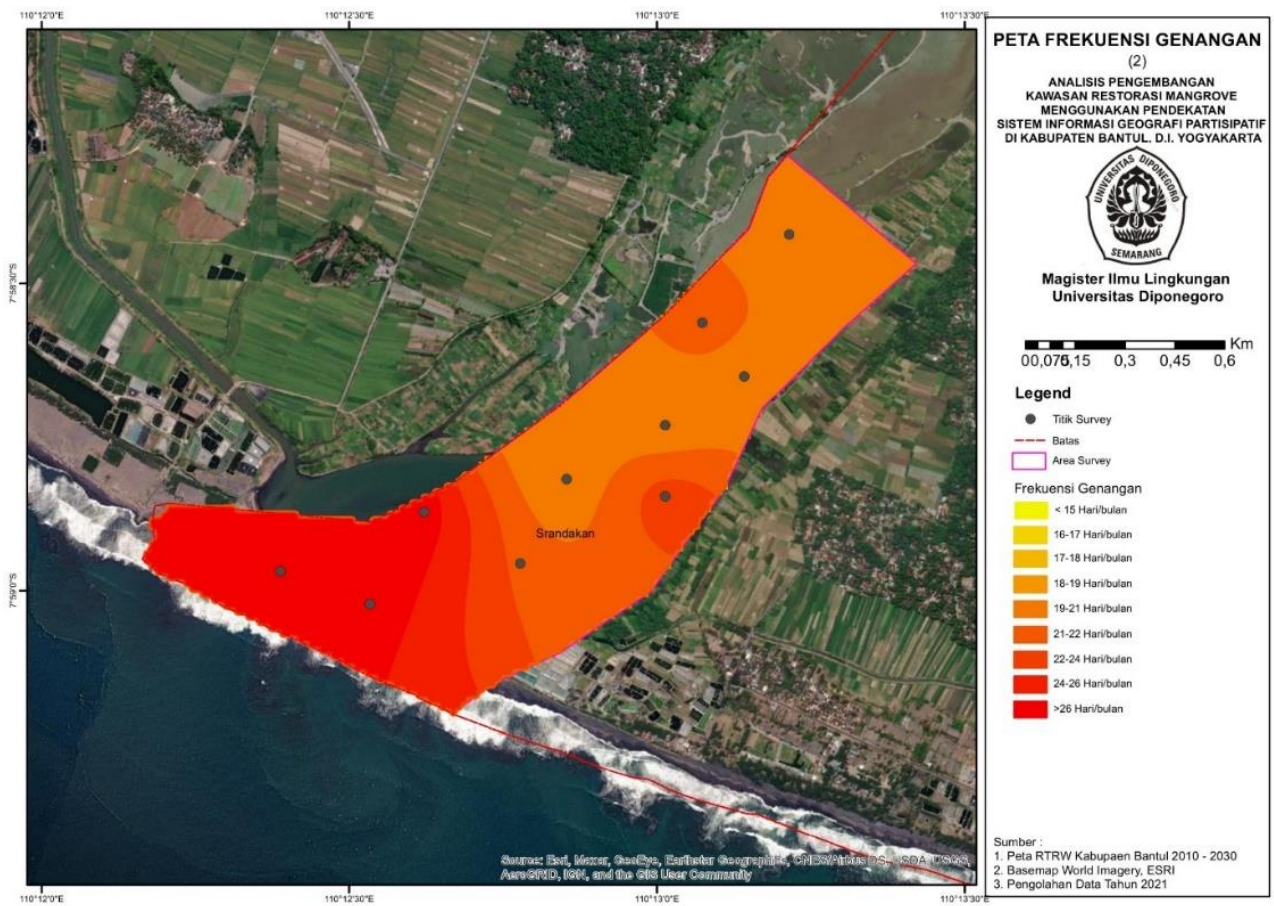

Fig. 5. Map of frequency inundation in Srandakan Districts, Bantul Regency, Indonesia.

The results show that the estuary area and open land are on average in the land use parameter. However, there are also areas where sand mining is utilised in the stations of $\mathrm{Sr} 1$, $\mathrm{Sr} 2$ and $\mathrm{Sr} 3$, Srandakan district. Even though they are included in the appropriate land criteria at these three stations, the score they have is only 6 . It shows that the three stations are at the minimum threshold for suitable land criteria to mangroves. Based on research, sand mining has caused soil change and damage, increasing bulk density, decreasing organic $\mathrm{C}$, decreasing and destroying soil microorganisms, also changes in soil physical properties, soil chemical properties and soil biology [28]. Sand mining activities have caused the loss of organic matter and biomass of mangrove forests, thus endangering sustainable forest management.

Table 3. The land use at each location point.

\begin{tabular}{|c|c|c|c|c|c|}
\hline $\begin{array}{c}\text { Station } \\
\text { Kretek }\end{array}$ & Land Use & $\begin{array}{c}\text { Station } \\
\text { Sanden }\end{array}$ & Land Use & $\begin{array}{c}\text { Station } \\
\text { Srandakan }\end{array}$ & Land Use \\
\hline $\mathrm{Kr} 1$ & $\begin{array}{c}\text { Mangroves / } \\
\text { open land }\end{array}$ & $\mathrm{Sa} 1$ & $\begin{array}{c}\text { Mangroves / } \\
\text { open land }\end{array}$ & $\mathrm{Sr} 1$ & mining \\
\hline $\mathrm{Kr} 2$ & $\begin{array}{c}\text { Mangroves / } \\
\text { open land }\end{array}$ & $\mathrm{Sa} 2$ & $\begin{array}{c}\text { Mangroves / } \\
\text { open land }\end{array}$ & $\mathrm{Sr} 2$ & mining \\
\hline $\mathrm{Kr} 3$ & $\begin{array}{c}\text { Mangroves / } \\
\text { open land }\end{array}$ & $\mathrm{Sa} 3$ & $\begin{array}{c}\text { Mangroves / } \\
\text { open land }\end{array}$ & $\mathrm{Sr} 3$ & mining \\
\hline $\mathrm{Kr} 4$ & $\begin{array}{c}\text { Mangroves / } \\
\text { open land }\end{array}$ & $\mathrm{Sa} 4$ & $\begin{array}{c}\text { Mangroves / } \\
\text { open land }\end{array}$ & $\mathrm{Sr} 4$ & $\begin{array}{c}\text { Mangroves / } \\
\text { open land }\end{array}$ \\
\hline $\mathrm{Kr} 5$ & $\begin{array}{c}\text { Mangroves / } \\
\text { open land }\end{array}$ & $\mathrm{Sa} 5$ & $\begin{array}{c}\text { Mangroves / } \\
\text { open land }\end{array}$ & $\mathrm{Sr} 5$ & $\begin{array}{c}\text { Mangroves / } \\
\text { open land }\end{array}$ \\
\hline
\end{tabular}




\begin{tabular}{|c|c|c|c|c|c|}
\hline Kr6 & $\begin{array}{l}\text { Mangroves / } \\
\text { open land }\end{array}$ & $\mathrm{Sa} 6$ & $\begin{array}{c}\text { Mangroves / } \\
\text { open land }\end{array}$ & Sr6 & $\begin{array}{c}\text { Mangroves / } \\
\text { open land }\end{array}$ \\
\hline $\mathrm{Kr} 7$ & $\begin{array}{c}\text { Mangroves / } \\
\text { open land }\end{array}$ & $\mathrm{Sa} 7$ & $\begin{array}{c}\text { Mangroves / } \\
\text { open land }\end{array}$ & $\mathrm{Sr} 7$ & $\begin{array}{c}\text { Mangroves / } \\
\text { open land }\end{array}$ \\
\hline $\mathrm{Kr} 8$ & $\begin{array}{c}\text { Mangroves / } \\
\text { open land }\end{array}$ & $\mathrm{Sa} 8$ & $\begin{array}{c}\text { Mangroves / } \\
\text { open land }\end{array}$ & Sr8 & $\begin{array}{c}\text { Mangroves / } \\
\text { open land }\end{array}$ \\
\hline $\mathrm{Kr} 9$ & $\begin{array}{c}\text { Mangroves / } \\
\text { open land }\end{array}$ & $\mathrm{Sa} 9$ & $\begin{array}{c}\text { Mangroves / } \\
\text { open land }\end{array}$ & Sr9 & $\begin{array}{c}\text { Mangroves / } \\
\text { open land }\end{array}$ \\
\hline $\mathrm{Kr} 10$ & $\begin{array}{l}\text { Mangroves / } \\
\text { open land }\end{array}$ & $\mathrm{Sa} 10$ & $\begin{array}{c}\text { Mangroves / } \\
\text { open land }\end{array}$ & Sr10 & $\begin{array}{c}\text { Mangroves / } \\
\text { open land }\end{array}$ \\
\hline Kr11 & $\begin{array}{c}\text { Mangroves / } \\
\text { open land }\end{array}$ & Sa11 & $\begin{array}{c}\text { Mangroves / } \\
\text { open land }\end{array}$ & & \\
\hline $\mathrm{Kr} 12$ & $\begin{array}{l}\text { Mangroves / } \\
\text { open land }\end{array}$ & $\mathrm{Sa} 12$ & $\begin{array}{c}\text { Mangroves / } \\
\text { open land }\end{array}$ & & \\
\hline Kr13 & $\begin{array}{c}\text { Mangroves / } \\
\text { open land }\end{array}$ & & & & \\
\hline Kr14 & $\begin{array}{c}\text { Mangroves / } \\
\text { open land }\end{array}$ & & & & \\
\hline Kr15 & $\begin{array}{l}\text { Mangroves / } \\
\text { open land }\end{array}$ & & & & \\
\hline Kr16 & $\begin{array}{l}\text { Mangroves / } \\
\text { open land }\end{array}$ & & & & \\
\hline Kr17 & $\begin{array}{l}\text { Mangroves / } \\
\text { open land }\end{array}$ & & & & \\
\hline
\end{tabular}

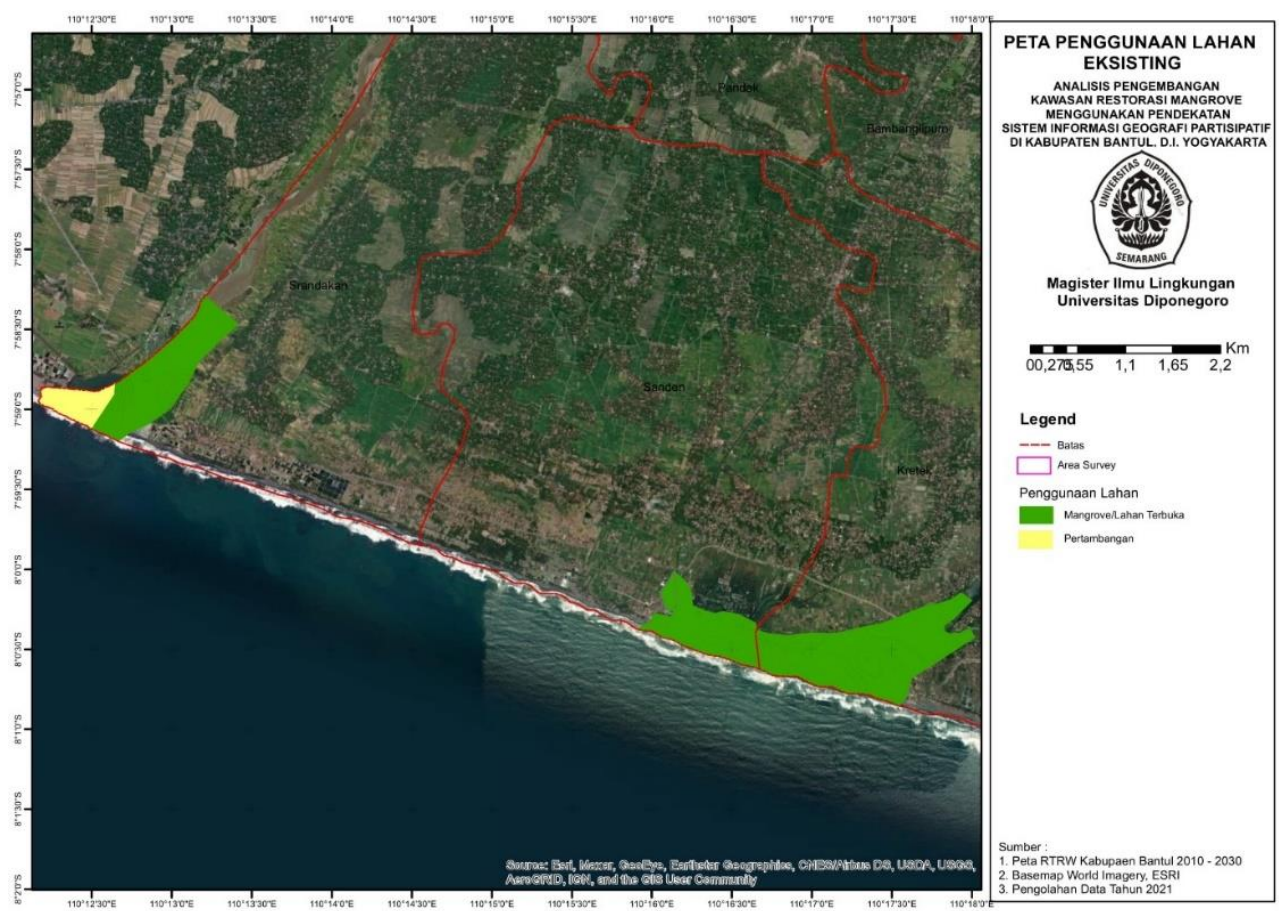

Fig. 6. Map of Land Use at the Research Site.

The results of the land suitability analysis using the equal interval show that the stations in the Kretek district obtained the very suitable assessment criteria for nine stations (LSV 1113) and the assessment criteria suitable to 8 stations (LSV 7-9). Likewise, the stations in 
Sanden and Srandakan districts can be observed in table 2. If the land suitability value (LSV) is averaged at the research location, the result in Kretek district is 10.29 (very suitable), Sanden district is 10, 83 (very suitable), and Srandakan district is 9, 5 (suitable).

Table 4. Value of Mangrove Land Suitability at Each Research Station.

\begin{tabular}{|c|c|c|c|c|c|c|c|c|}
\hline $\begin{array}{l}\text { Station } \\
\text { Kretek }\end{array}$ & LSV & Class & $\begin{array}{l}\text { Station } \\
\text { Sanden }\end{array}$ & LSV & Class & $\begin{array}{c}\text { Station } \\
\text { Srandakan }\end{array}$ & LSV & Class \\
\hline $\mathrm{Kr} 1$ & 11 & S1 & Sal & 11 & S1 & Sr1 & 6 & $\mathrm{~S} 2$ \\
\hline $\mathrm{Kr} 2$ & 11 & S1 & $\mathrm{Sa} 2$ & 13 & S1 & $\mathrm{Sr} 2$ & 6 & S2 \\
\hline $\mathrm{Kr} 3$ & 13 & S1 & $\mathrm{Sa} 3$ & 11 & S1 & Sr3 & 6 & $\mathrm{~S} 2$ \\
\hline $\mathrm{Kr} 4$ & 11 & S1 & $\mathrm{Sa} 4$ & 9 & S2 & $\mathrm{Sr} 4$ & 13 & $\mathrm{~S} 1$ \\
\hline $\mathrm{Kr} 5$ & 13 & S1 & $\mathrm{Sa} 5$ & 11 & S1 & Sr5 & 9 & S2 \\
\hline Kr6 & 13 & S1 & $\mathrm{Sa} 6$ & 13 & S1 & Sr6 & 9 & $\mathrm{~S} 2$ \\
\hline $\mathrm{Kr} 7$ & 11 & S1 & $\mathrm{Sa} 7$ & 11 & S1 & Sr7 & 13 & S1 \\
\hline Kr8 & 9 & S2 & $\mathrm{Sa} 8$ & 11 & S1 & Sr8 & 13 & S1 \\
\hline $\mathrm{Kr} 9$ & 11 & S1 & $\mathrm{Sa} 9$ & 15 & S1 & Sr9 & 7 & S2 \\
\hline $\mathrm{Kr} 10$ & 9 & S2 & $\mathrm{Sa} 10$ & 9 & S2 & Sr10 & 13 & S1 \\
\hline Kr11 & 7 & S2 & Sa11 & 9 & S2 & & & \\
\hline $\mathrm{Kr} 12$ & 7 & S2 & Sa12 & 7 & S2 & & & \\
\hline $\mathrm{Kr} 13$ & 9 & S2 & & & & & & \\
\hline $\mathrm{Kr} 14$ & 9 & S2 & & & & & & \\
\hline $\mathrm{Kr} 15$ & 9 & S2 & & & & & & \\
\hline Kr16 & 13 & S1 & & & & & & \\
\hline $\mathrm{Kr} 17$ & 9 & S2 & & & & & & \\
\hline
\end{tabular}

Information : $\mathrm{S} 1$ = very suitable, $\mathrm{S} 2$ = suitable, $\mathrm{S} 3$ = conditionally suitable. 


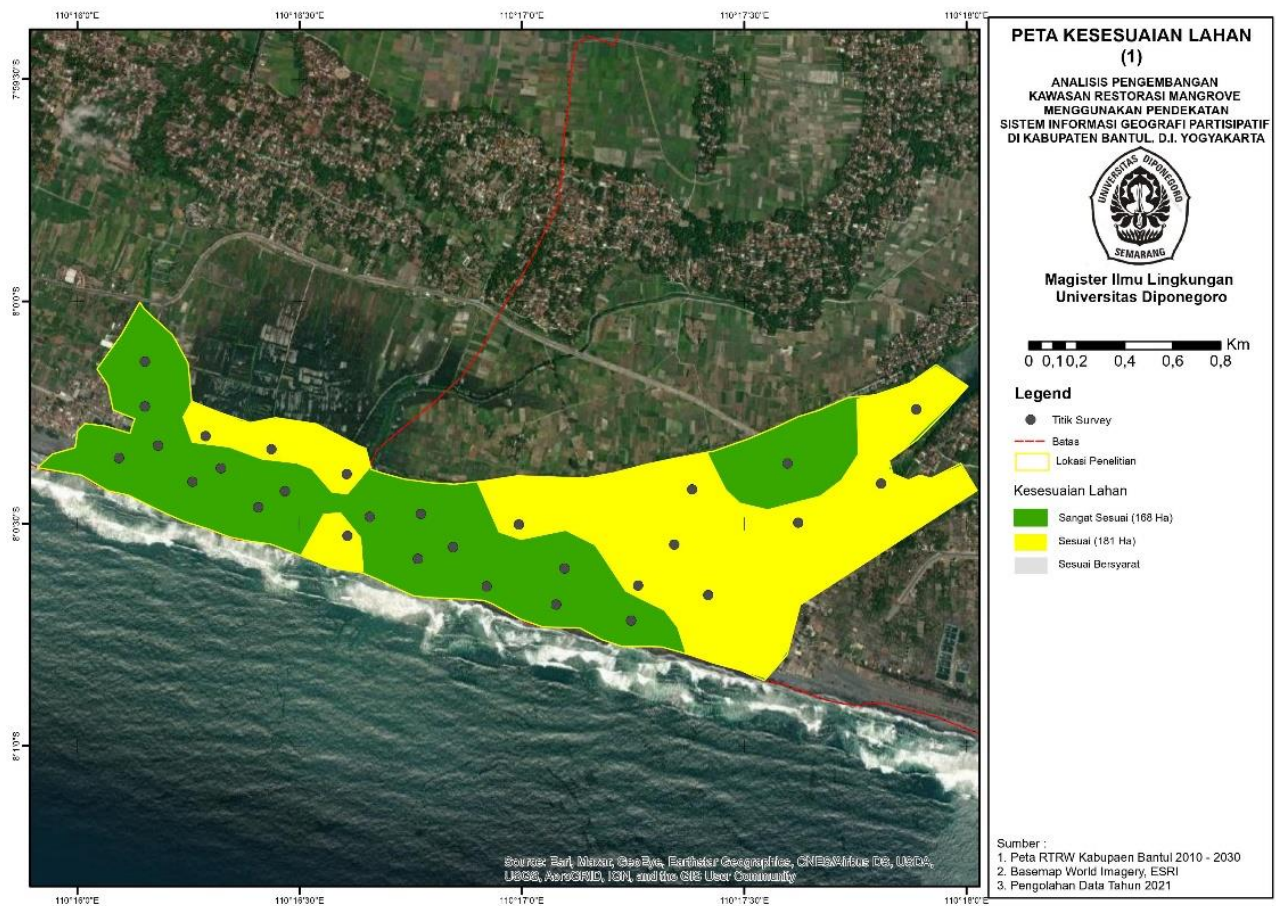

Fig. 7. map of mangrove land suitability at Kretek and Sanden Districts, Bantul Regency, Indonesia

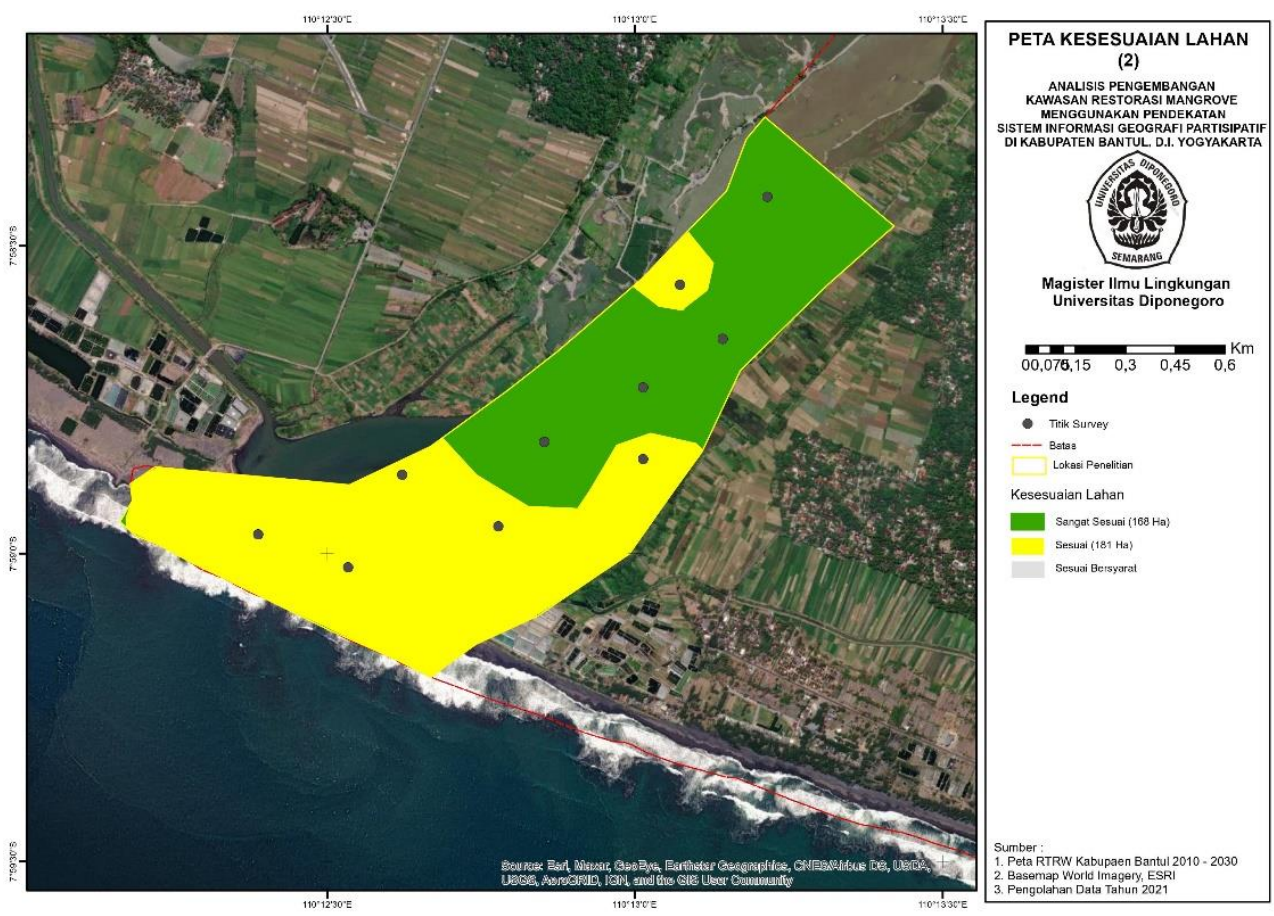

Fig. 8. map of mangrove land suitability at Srandakan Districts, Bantul Regency, Indonesia.

After analyzing the geospatial method, it was found that the very suitable class area for mangrove restoration land was 168 ha and the suitable class was 181 ha. However, some of 
the physical parameters analyzed in this study are insufficient to develop disaster management efforts or sustain climate change mitigation efforts. It still requires a community development approach from planning, planting, maintenance, and management to achieve mangrove cultivation [29].

\section{Conclusions}

Based on this research, it can be concluded that the suitability of mangrove restoration land can be carried out at locations based on priority parameters in Kretek district, Sanden district (Opak Estuary River) and Srandakan District (Progo Estuary River). After analyzing the geospatial method, it was found that the very suitable class area for mangrove restoration land was 168 ha and the suitable class was 181 ha.

\section{Acknowledgement}

Thank you to the head of the Mangrove group in Sanden district, Bantul regency, CV. Maheswari Bumi for assisting in completion of this research.

\section{References}

1. C. Giri, E. Ochieng, L. L. Tieszen, Z. Zhu, A. Singh, T. Loveland, J. Masek, N. Duke, Glob. Ecol. Biogeogr., 20, 154 (2011)

2. J. Chow, J. Sustain. For., 37, 139 (2018)

3. D. Murdiyarso, J. Purbopuspito, J. B. Kauffman, M. W. Warren, S. D. Sasmito, D. C. Donato, S. Manuri, H. Krisnawati, S. Taberima, S. Kurnianto, Nat. Clim. Chang., 5, 1089 (2015)

4. D. C. Donato, J. B. Kauffman, D. Murdiyarso, S. Kurnianto, M. Stidham, M. Kanninen, Nat. Geosci., 4, 293 (2011)

5. R. DasGupta, R. Shaw, J. Ecosyst., 2013, 1 (2013)

6. R. Fitri, K. Anwar, J. FISIP, 1, 1 (2014)

7. S. Eddy, A. Mulyana, M. S. Dr. Moh. Rasyid Ridho, M. S. Prof. Dr. Iskhaq Iskandar, 1, 240 (2017)

8. A. N. Indah, Domistic Case Study, 9, (2019)

9. N. P. D. M. N. Setiawan, Analisis Kesesuaian Habitat Mangrove Pada Kawasan Mangrove Buatan Baros Bantul, Daerah Istimewa Yogyakarta, (Universitas Gadjah Mada Yogyakarta, 2013)

10. P. Subardjo, R. Ario, J. Kelaut. Trop., 18, 82 (2016)

11. H. Y. L. Totok Wahyu Wibowo, E. A. W. Putri, Pros. Semin. Nas. Geogr., UMS, 8, 343-355 (2017)

12. Zaky et al, J. Mar. Res., 1, 88 (2012)

13. Indratin, M. A. Budihardjo, M. Helmi, E3S Web Conf., 202, (2020)

14. Poniman, T. R. Soeprobowowati, M. Helmi, E3S Web Conf., 202, (2020)

15. Iswandi, M. Helmi, Hadiyanto, IOP Conf. Ser. Earth Environ. Sci., 448, (2020)

16. N. Sudirman, M. Helmi, N. S. Adi, E3S Web Conf., 73, (2018)

17. H. S. H. M.Helmi, A. Satriadi, A. A. Dwi Suryoputro, J. Marwoto, Int. J. Civ. Eng. Technol., 9, 2949 (2018) 
18. R. W. M. Helmi, Y. H. Pholandani, H. Setiyono, A. Wirasatriya, W. Atmodjo, A. A. D. S. I, Int. J. Sci. Technol. Res., 9, (2020)

19. T. T. Putranto, T. Amanah, B. Warsito, H. Purnaweni, M. Helmi, Int. J. Geomate, 18, $124(2020)$

20. B. W. Mutaqin, M. A. Marfai, M. Helmi, M. G. Rindarjono, R. Windayati, Sunarto, IOP Conf. Ser. Earth Environ. Sci., 451, (2020)

21. M. M. Helmi, A. Aysira, R. W., A. Wirasatria, R. Ario, Indones. J. Oceanogr., 2, 8 (2020)

22. A. D. P. C. P. S. Budhi, N. Latifah, Semin. Nas. Penginderaan Jauh Ke 6, 8, 439 (2019)

23. A. T. M. A. D. Savitri, Junianto, J. Perikan. Dan Kelaut., 3, 301 (2012)

24. F. I. D. S. Wahyuningsih, M. D. Putra, Th. R. Wulan, S. P. Anggara, E. Maulana, Semin. Nas. Geogr., UMS 8, (2016)

25. R. V. S. E. Mlcleod, Managing Mangroves for Resilience to Climate Change, (2006)

26. Dahuri, Keanekaragaman Hayati Laut: Aset Pembangunan Berkelanjutan Indonesia (PT. Gramedia Pustaka, 2003)

27. E. M. G.B. Saputro, M.I.C. Marschiavelli, F.Ibrahim, IOP Conf. Ser. Earth Environ. Sci., 54, 1 (2017)

28. B. Wasis, Dep. Silvikultur Fak. Kehutan. IPB. Res., 12, 3 (2020)

29. F. Fatimatuzzahroh, S. P. Hadi, H. Purnaweni, E3S Web Conf., 31, 2017 (2018) 